\title{
ANALYSIS OF KIDNEY STONES BY FTIR SPECTROSCOPY
}

\author{
Naseem Aslam Channa, Allah Bux Ghangro, Ali Muhammad Soomro and Lubna Noorani
}

\begin{abstract}
OBJECTIVE: This study was carried out to investigate the composition and type of kidney stones in our population.

DESIGN: Analytical study.

SETTING: Kidney stones recovered from patients of different hospitals of Hyderabad and adjoining areas (Liaquat University Hospital Jamshoro, Memon Charitable Hospital Hyderabad, Wali Bhai Rajputana Hospital Hyderabad, Naseem Medical Center Hyderabad and Isra University Hospital, Hyderabad, Sindh) during 2005 - 2006.

MATERIAL AND METHODS: A total of 58 kidney stone samples were collected randomly and analyzed for composition by Fourier Transform Infrared Spectroscopy (FTIR).

RESULTS: Of 58 kidney stone samples, $37.9 \%$ were pure calcium oxalate stones, $3.4 \%$ were uric acid, $44 \%$ calcium oxalate + uric acid, $3.4 \%$ calcium oxalate + aspartate and $10.3 \%$ were magnesium ammonium phosphate. The IR bands were compared with standards. Gender wise comparison revealed that majority of the stones $(68.9 \%)$ analyzed were recovered from male patients. Whereas, stones recovered from females were only $31.1 \%$. Age wise comparison data disclosed that age range for the presentation of kidney stone disease was 15-29 years.

CONCLUSION: Calcium oxalate + uric acid stones are commonly found in patients of Hyderabad and adjoining areas.
\end{abstract}

KEY WORDS: Kidney stones. Fourier Transform Infrared. FTIR. Calcium oxalate stones.

\section{INTRODUCTION}

Kidney stone disease is a common disease with multifactorial etiopathogenesis. ${ }^{1,2}$ Its prevalence in Western populations is $\sim 10 \%,{ }^{3,4}$ although geographical and ethnic differences among populations have also been reported. ${ }^{5}$ The majority of stone formers have disturbances either in the metabolism and excretion of stone constituents or in promoters ${ }^{6}$ and inhibitors of crystallization. ${ }^{7}$ Clinical and epidemiological studies have documented that several types of risk factors are involved in disease etiology, such as dietary habits, warm climate, and familial occurrence. . $^{1,8}$

The identification of the components of gallstones is essential as it provides information that could be useful for practitioners to find out the underlying cause of kidney stones and to decide whether to treat kidney stone patients therapeutically or surgically. Unfortunately, gallstone composition is heterogeneous, and varies within and amongst the populations around the world. ${ }^{9,11}$ A study of the chemical composition of renal stones is important for understanding their etiology as well. And the therapy for the stone disease is usually based on the analysis of calculi, permitting a proper management of the disease and the prevention of its recurrence. FTIR spectroscopy has been used for urinary stones analysis. ${ }^{9}$ The routine, easy and rapid measurements give unambiguous information about the stone composition. ${ }^{10}$ Specially a precise wavelength scale of the Fourier method is helpful here. A relatively good spatial resolution is important as very often the stones are composed of core and various layers of different chemical composition.

As the composition of urinary stones varies from place to place, ${ }^{11}$ the present study was therefore undertaken to investigate the common types of the stones and their possible etiological factors for the better management of the patients clinically. Regardless of the selected treatment, for proper management of patients with recurrent stone formation (approximately $80 \%$ of the stone-forming patients), qualitative and quantitative analysis of all crystal material present in kidney stones is essential to guide therapy. ${ }^{10}$

\section{MATERIAL AND METHODS}

The materials for this study were kidney stones surgically recovered from 58 (40 males and 18 females, mean age range $14-45$ years) patients. All stones removed during surgery were placed on sterile wire 
gauze to air dry, transferred into a paper plastic envelope bearing the sample number. All specimens were first washed carefully with distilled deionized water and dried over silica gel for several days. After noting the morphological features such as color, shape, etc kidney stones from each patient were cut into quarters using a jeweler's saw and one quarter was ground with agate pestle and mortar. This procedure produced a fine homogenous powder which was then stored in a sample tube, kept over silica gel in dark until analyzed for composition by FTIR.

The FTIR spectroscopy was performed using Nicollet Avatar 330 FTIR Spectrophotometer by Thermo Electronic Corporation in the frequency range $600-4000$ $\mathrm{cm}-1$. To obtain a high signal/ noise ratio 32 scan were accumulated for each sample. Initially the spectra were fitted for parabolic function. Then RMS (Route mean square) was calculated between the original spectrum and the one, fitted by the function. The area under the fitted spectrum was dividing by the noise RMS, which is reported as signal / noise ratio (SNR). The evaluate menu provided in the Omnic (7.0 version) software perform the entire process automatically. Standard spectra for most common crystalline compounds Calcium Oxalate (Monohydrated), Magnesium ammonium phosphate (Hexahydrate), Uric acid, L-Cystine, Calcium Carbonate, L - Aspartic acid, LGlutamic acid) in stones were prepared, which were of high quality (99\%) pure purchased from E. Merck (West Germany). For each FTIR measurement, only homogeneous stone powder was used. The $\mathrm{ZnSe}$ crystal in the FTIR setup was $80 \times 10 \mathrm{~mm}$ and its thickness was $4 \mathrm{~mm}$. Vector normalization was applied to all the FTIR spectra reported in this study. Calcium carbonate was measured using the peaks at 1403 and $855 \mathrm{~cm}-1$. As an internal check, the component subtraction spectra were recombined and original spectrum was produced with an error of $2 \%$ to $4 \%{ }^{12}$ All kidney stones were analyzed using the well validated method described by Sloway and Wu for gallstone analysis on FTIR. ${ }^{13}$

\section{RESULTS}

Typical FTIR spectra of seven different standards are shown in Figures 1 to 7, which are compared with the FTIR spectra of kidney stone samples. Figures 8 to 12 show those typical FTIR spectra of some kidney stone samples which were $\geq 90 \%$ matched with the spectra of standards and identified. Table I presents the type of kidney stones identified and their frequency of occurrence. Of the 58 kidney stones, $37.9 \%$ were identified as calcium oxalate, $3.4 \%$ pure uric acid, $10.3 \%$ magnesium ammonium phosphate and $44 \%$ were identified as uric acid + calcium oxalate. The diagnostic bands identified for calcium oxalate were the strong bands around 778.96, 1315.62, $166.87 \mathrm{~cm}^{-1}$, pure uric acid $1638.10 \mathrm{~cm}^{-1}$, magnesium ammonium phosphate $2362.67,1459.29 \mathrm{~cm}^{-1}$, calcium oxalate and L- aspartate 1607.28, 1315.24, 1306.9 $\mathrm{cm}^{-1}$ and for uric acid + calcium oxalate were around 778.93, 778.53, 1314.93, 740.18, 1637.46, 1314.27, and $1635.66 \mathrm{~cm}^{-1}$ respectively ${ }^{14}$ (Table II). Genderwise comparison revealed that majority $(68.9 \%)$ of kidney stones were recovered from the male patients (Table III). Age wise comparison of the data (Table IV) disclosed that majority of stones (37.9\%) were recovered from the patients of age group $30-44$ years. Children of 1-14 years age were also more prone to develop kidney stones (31.0\%).

FIGURE I:

\section{TYPICAL FTIR SPECTRA OF CALCIUM CARBONATE STANDARD}

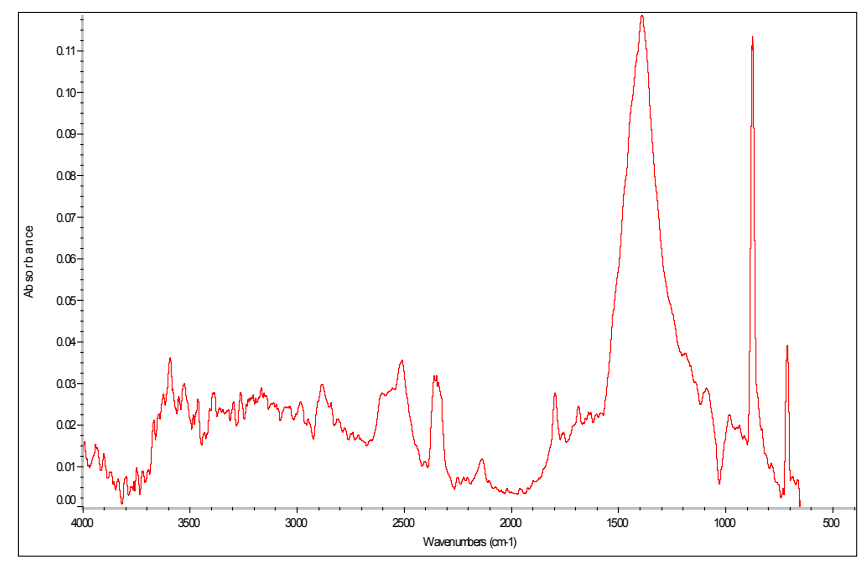

FIGURE II:

TYPICAL FTIR SPECTRA OF CALCIUM OXALATE STANDARD

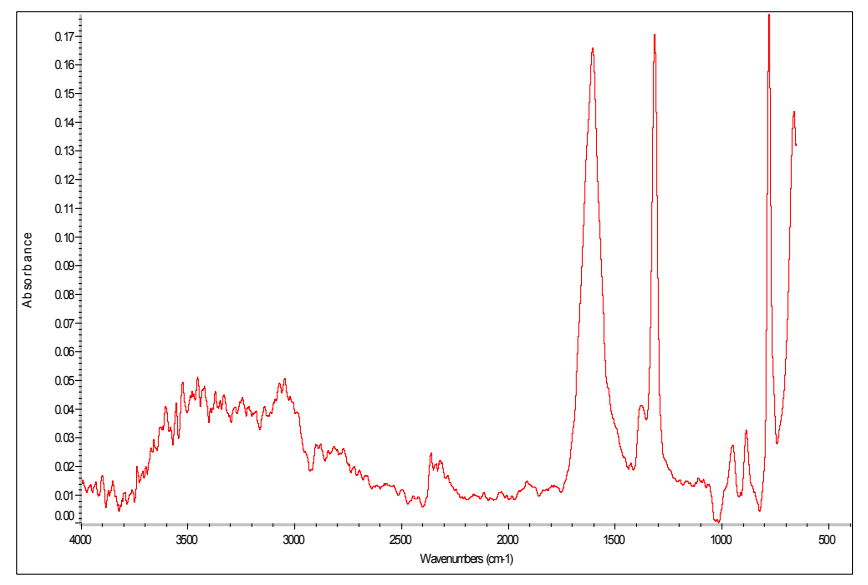


FIGURE III:

TYPICAL FTIR SPECTRUM OF URIC ACID STANDARD

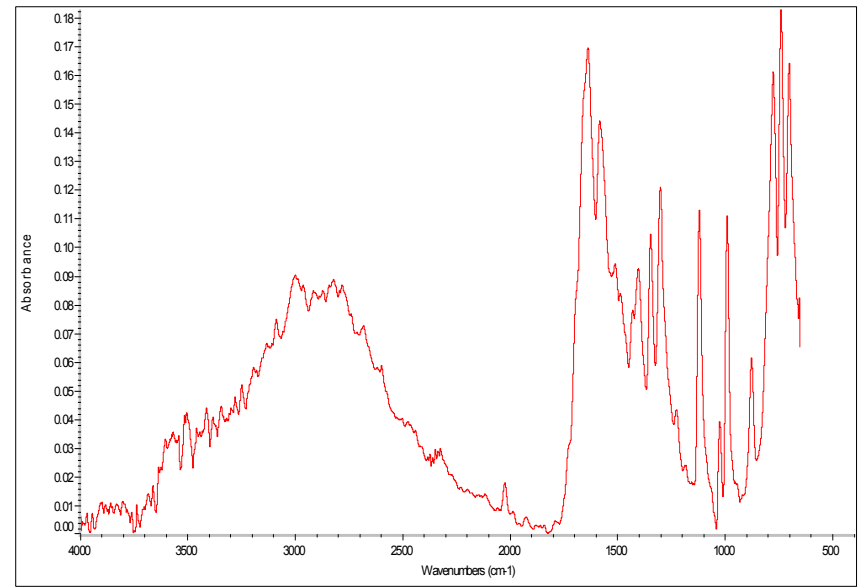

FIGURE IV:

TYPICAL FTIR SPECTRUM OF MAGNESIUM AMMONIUM PHOSPHATE STANDARD

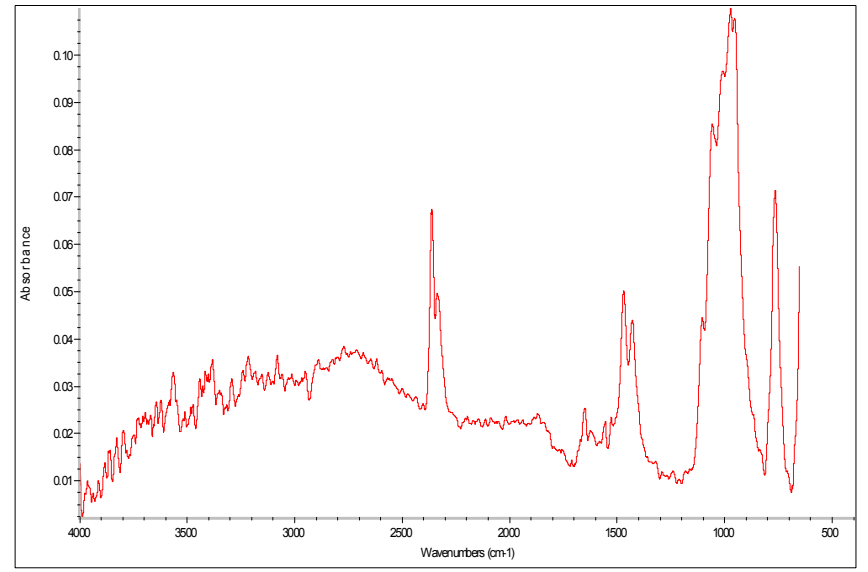

FIGURE V:

TYPICAL FTIR SPECTRUM OF L - CYSTEIN STANDARD

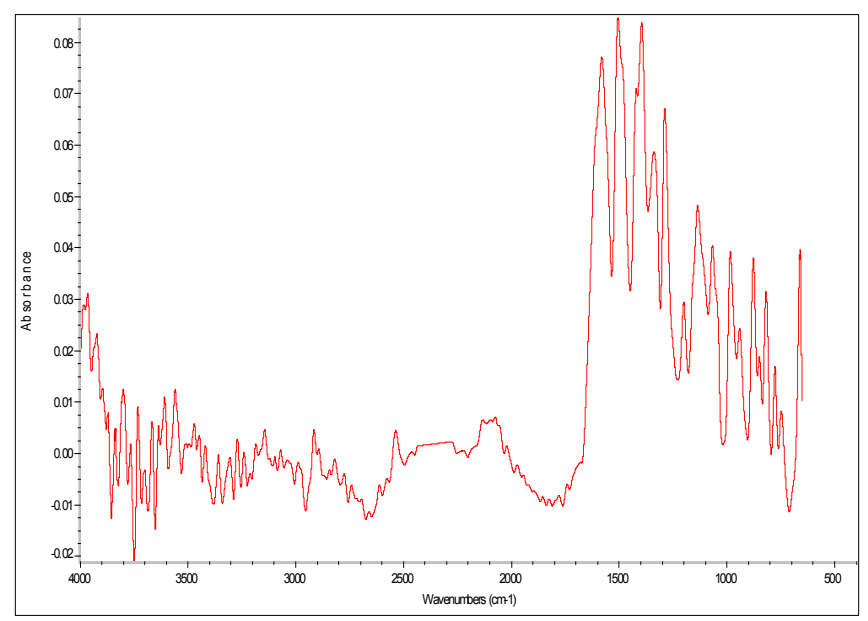

FIGURE VI:

TYPICAL FTIR SPECTRUM OF L - ASPARTATE STANDARD

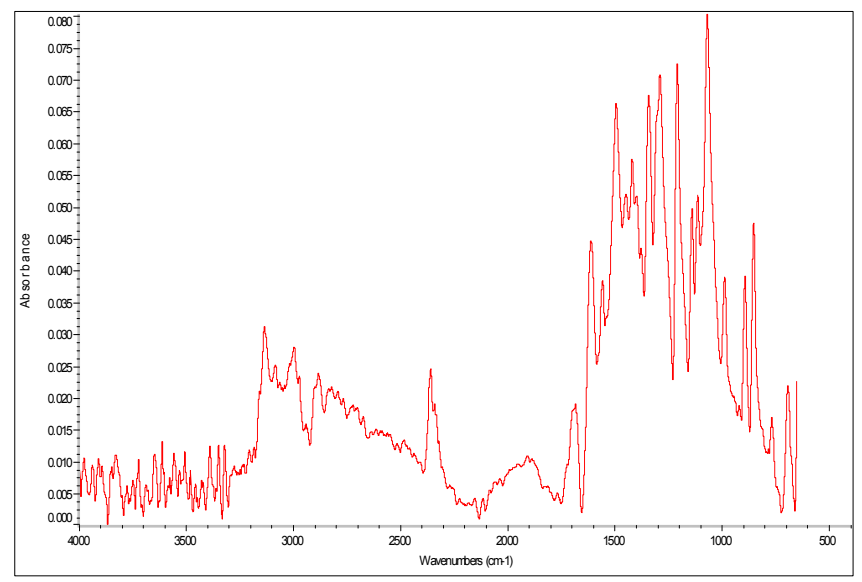

FIGURE VII:

TYPICAL FTIR SPECTRUM OF L - GLUTAMINE STANDARD

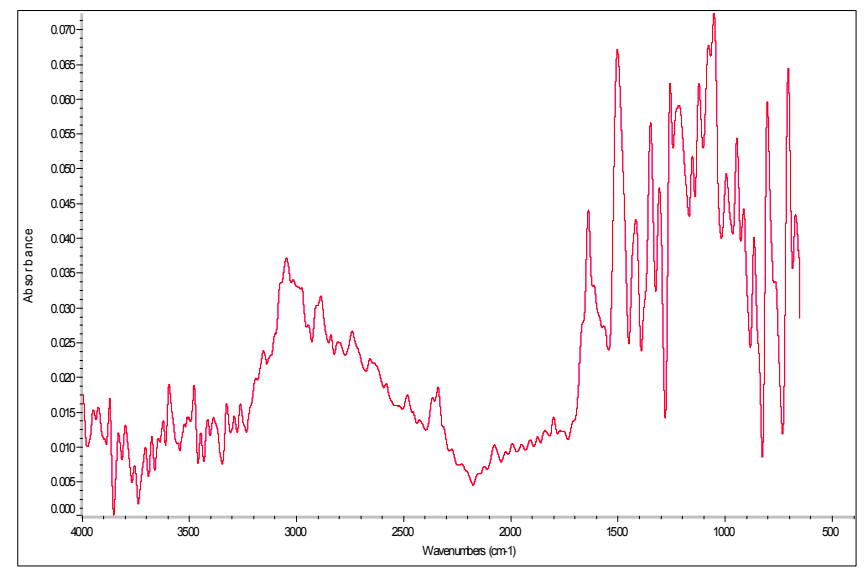

FIGURE VIII:

TYPICAL FTIR SPECTRUM OF PURE URIC ACID KIDNEY STONE SAMPLE

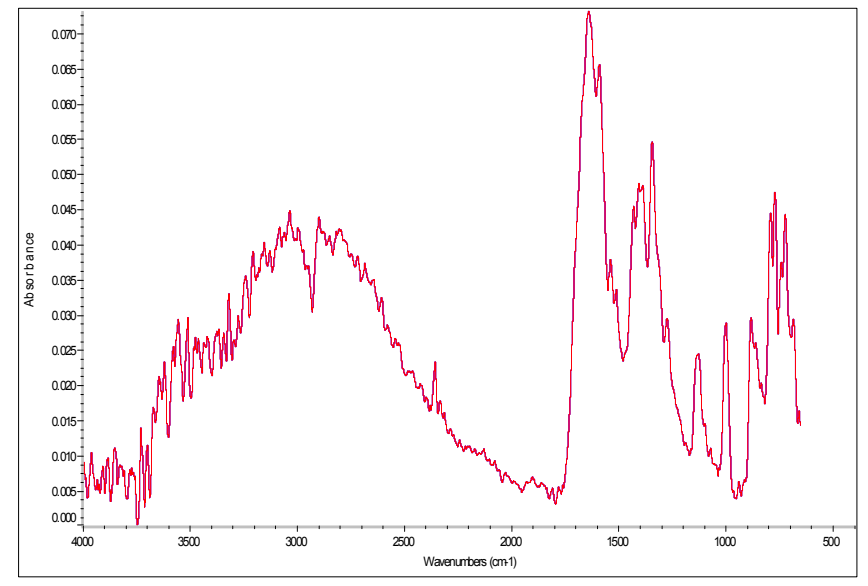




\section{FIGURE IX:}

TYPICAL FTIR SPECTRUM OF PURE CALCIUM OXALATE KIDNEY STONE SAMPLE

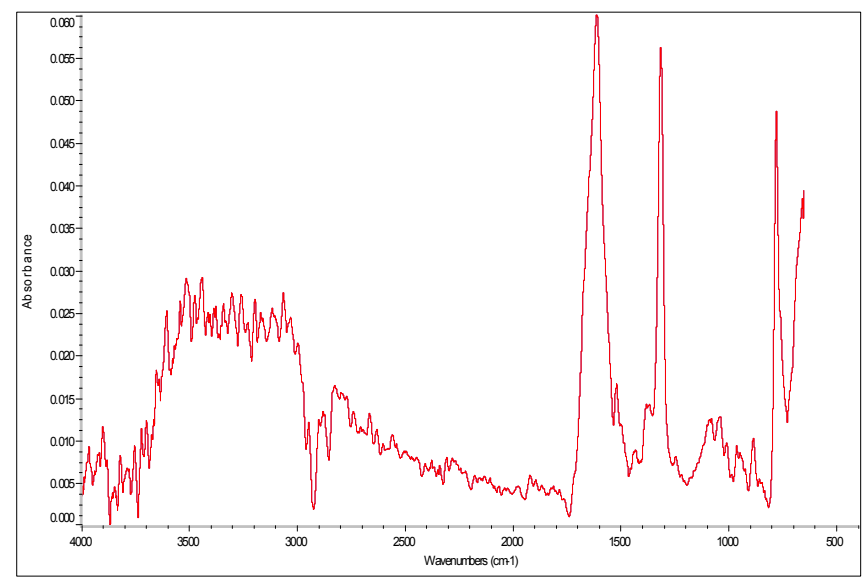

FIGURE X:

TYPICAL FTIR SPECTRUM OF CALCIUM OXALATE + URIC ACID KIDNEY STONE SAMPLE

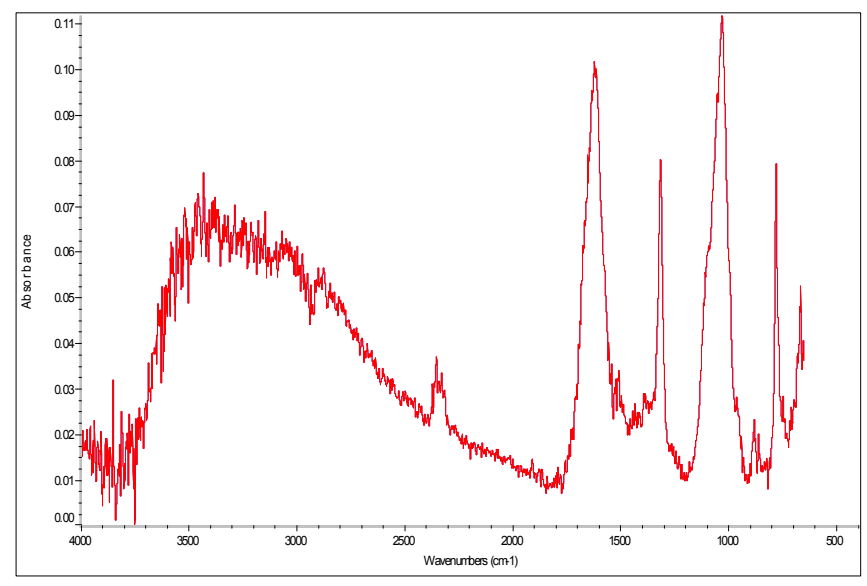

FIGURE XI:

TYPICAL FTIR SPECTRUM OF CALCIUM OXALATE + ASPARTATE KIDNEY STONE SAMPLE

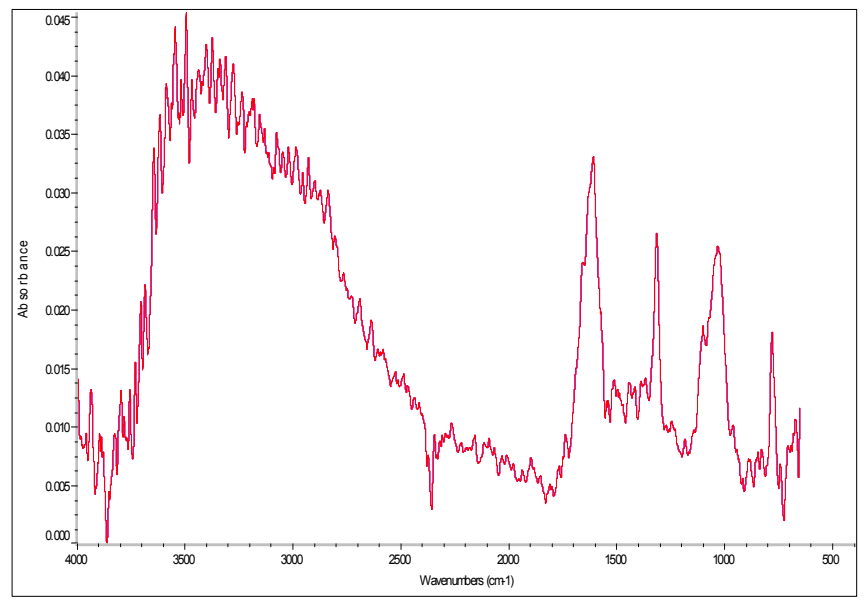

FIGURE XII:

TYPICAL FTIR SPECTRUM OF MAGNESIUM PHOSPHATE KIDNEY STONE SAMPLE

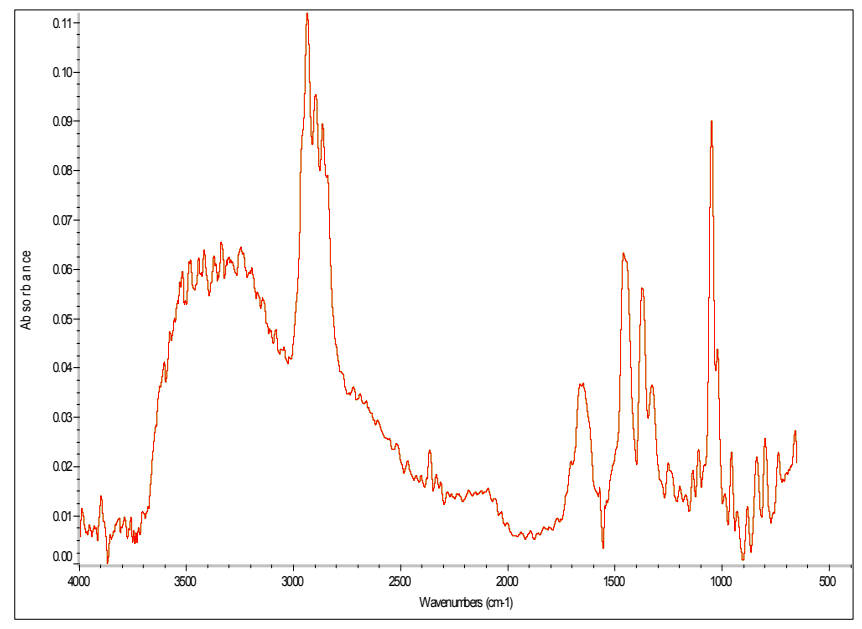

TABLE I:

TYPES OF STONES RECOVERED FROM KIDNEY STONE PATIENTS

\begin{tabular}{|l|c|c|}
\hline \multicolumn{1}{|c|}{ Type of Stone } & $\begin{array}{c}\text { No. of } \\
\text { Stones(n=58) }\end{array}$ & Percentage \\
\hline $\begin{array}{l}\text { Calcium oxalate } \\
\text { (pure) }\end{array}$ & 22 & $37.9 \%$ \\
\hline Uric acid (pure) & 02 & $3.4 \%$ \\
\hline $\begin{array}{l}\text { Calcium oxalate }+ \\
\text { uric acid }\end{array}$ & 26 & $44 \%$ \\
\hline $\begin{array}{l}\text { Calcium oxalate }+ \\
\text { aspartate }\end{array}$ & 02 & $3.4 \%$ \\
\hline $\begin{array}{l}\text { Magnesium } \\
\text { ammonium phosphate } \\
\text { (struvite) }\end{array}$ & 06 & $10.3 \%$ \\
\hline
\end{tabular}

TABLE III:

GENDER WISE COMPARISON OF KIDNEY STONES RECOVERED FROM PATIENTS

\begin{tabular}{|l|c|c|}
\hline \multicolumn{1}{|c|}{ Gender } & No. of Stones & Percentage \\
\hline Male & 40 & $68.9 \%$ \\
\hline Female & 18 & $31.0 \%$ \\
\hline
\end{tabular}


TABLE II:

TYPE, OCCURRENCE AND IR BANDS OF PRINCIPLE COMPONENTS OBSERVED IN KIDNEY STONES

\begin{tabular}{|l|c|l|l|}
\hline \multicolumn{1}{|c|}{ Types of Stone } & $\begin{array}{c}\text { Occurrence } \\
(\mathbf{n = 5 8 )}\end{array}$ & $\begin{array}{c}\text { Principle IR-bands } \\
\text { observed in present study }\end{array}$ & $\begin{array}{l}\text { IR-bands observed in stan- } \\
\text { dards and literature }{ }^{14}\end{array}$ \\
\hline Calcium oxalate (pure) & 22 & $\begin{array}{l}778.96,1315.62, \\
1606.87\end{array}$ & $\begin{array}{l}778.53(\mathrm{C}=\mathrm{O} \text { asymmetrical } \\
\text { stretching), 1314.93 (C-C } \\
\text { symmetrical stretching), } \\
1604.64(\mathrm{OC}=\mathrm{O} \text { asymmetri- } \\
\text { cal stretching) }\end{array}$ \\
\hline Uric acid (pure) & 02 & $1638.10,1021.05$ & $\begin{array}{l}1637.29(\mathrm{C}=\mathrm{C} \text { stretching), } \\
1018.13(\mathrm{~N}-\mathrm{H} \text { stretching), } \\
738.03(\mathrm{C}-\mathrm{N} \text { stretching of } \\
\text { aromatic) }\end{array}$ \\
\hline $\begin{array}{l}\text { Magnesium ammonium phosphate } \\
\text { (struvite) }\end{array}$ & 06 & $2362.67,1459.29$ & $\begin{array}{l}\text { 2362.63 (N-H and C-H } \\
\text { stretching), 1469.19 (NH }{ }_{3}^{+} \\
\text {symmetrical bending), } \\
\text { 970.53 (P-O-C aliphatic } \\
\text { stretching) }\end{array}$ \\
\hline Calcium oxalate + uric acid & 26 & $\begin{array}{l}1019,1314.27,1637.46, \\
1635.66\end{array}$ & $\begin{array}{l}\text { Same as Calcium oxalate, } \\
\text { and uric acid }\end{array}$ \\
\hline Calcium oxalate+aspartate & 02 & $\begin{array}{l}\text { Same as in Calcium oxalate, } \\
1607.28,1315.24,1030.69\end{array}$ & $\begin{array}{l}\text { Same as Calcium oxalate, } \\
1238.51(\mathrm{C}-\mathrm{N} \text { stretching), } \\
1208.64(\mathrm{C}-\mathrm{C}(=\mathrm{O})-\mathrm{O} \text { stretch- } \\
\text { ing), 1068.02 (C-CO-O-CO- } \\
\text { C stretching) }\end{array}$ \\
\hline
\end{tabular}

TABLE IV:

AGE WISE COMPARISON OF KIDNEY STONES RECOVERED FROM PATIENTS

\begin{tabular}{|l|c|c|}
\hline Age (years) & No. of Patients & Percentage \\
\hline $0-14$ & 18 & $31.0 \%$ \\
\hline $15-29$ & 06 & $10.3 \%$ \\
\hline $30-44$ & 22 & $37.9 \%$ \\
\hline 45 and above & 12 & $20.6 \%$ \\
\hline
\end{tabular}

\section{DISCUSSION}

The information of chemical composition of renal stones is essential for knowing their etiology. The therapy for the renal stone disease is also based on analysis of calculi, and by the help of chemical composition, proper management of the disease, and prevention of its recurrence is possible.

Calcium oxalate stones mainly develop due to hyper- oxaluria, which is a metabolic disorder that causes the stone formation. ${ }^{15}$ Oxalate is end product of several metabolic pathways (including those involving in serine, glycine, hydroproline and ascorbate). 10 to $20 \%$ urinary oxalate is derived from dietary sources and foods rich in oxalate are cranberries, ${ }^{16}$ spinach, chocolate and tea. ${ }^{16,17}$ Hypercalciuria related to stone formation may result from renal tubular leaking, increased gastrointestinal absorption of calcium, and hyperparathyroidism. ${ }^{18}$ Urine oxalate concentration affects calcium oxalate supersaturation as does urine calcium concentration. ${ }^{19}$ Hence, any condition that increases oxalate absorption from food may lead to increased oxalate production and cause calcium oxalate stone formation. ${ }^{20}$ Massey et al. (2005) reported that $1000 \mathrm{mg}$ ascorbic acid twice each day increased urinary oxalate and Tiselius Risk Index (TRI) for calcium oxalate kidney stones in $40 \%$ of participants, both stone formers and non-stone formers. ${ }^{21}$ The patients in present study were great consumers of leafy 
vegetables (spinach, saag) and tea. And stones recovered from those were oxalate containing stones including pure calcium oxalate, calcium oxalate + aspartate and uric acid. We found a relatively low percentage $(3.4 \%)$ of patients who developed pure uric acid stones. According to Morton et al. the pure uric acid stones are relatively rare. ${ }^{16}$ Reduced urinary $\mathrm{pH}$ could be an important risk factor for uric acid stone formation. ${ }^{22,23}$ For acidification of urine, several processes are responsible. One mechanism is $\mathrm{NH}_{3}$ production from glutamine, which takes place in the proximal tubule. ${ }^{24,25} \mathrm{~A}$ reduced $\mathrm{NH}_{3}$ production resulting in a decreased buffer capacity for $\mathrm{H}^{+}$ions (caused by lack of glutamine or by an enzymatic defect) is considered a potential mechanism for permanently low urinary $\mathrm{pH}$ in uric acid stone formers. Uric acid is the end product of purine degradation in humans, and the kidney plays a predominant role in its elimination. The molecular basis for renal urate transport, however, has not been completely defined. Uric acid stone can also be developed from excessive intake of meat and fish, ${ }^{16}$ although hyperuricosuria results from high dietary intake of beef, poultry and fish can lead to stone formation. ${ }^{20}$ We found $10.3 \%$ struvite stones, formation of these calculi is due to urinary infection, and thus treatment involves pharmacological (antibiotic) intervention. ${ }^{26}$ To prevent recurrent infections, it is recommended that urinary $\mathrm{pH}$ values be maintained below 6.0. The diets influence on urinary $\mathrm{pH}$ may be animal protein, vegetarian diets, soft drinks, citrus rich beverages and citrus juices. ${ }^{27}$ These types of stones are also formed by infection of urea splitting microbes. $^{16,28}$ However, Fedric et al. suggested that struvite or magnesium ammonium phosphate produced during the infection with bacteria that possesses the enzyme urease and its incidence is about $10 \%$ among all other stones. ${ }^{17}$ The males were greatly affected by the renal calculi as compared to female; it may be because of the low citrate content in males as compared to females. ${ }^{15,29,30,31}$ Citrate is an inhibitor of stone formation, which is derived from both endogenous (TCA cycle) and exogenous sources (citrus fruit such as oranges and Grape fruits). ${ }^{32,33}$ However, a bulk of urinary citrate is a result of renal tubular cell excretion, when renal tubular cell excretion of citrate decrease, hypocitraturia occurs which leads to the formation of renal stone. ${ }^{16}$ Majority of stones recovered from patients were composed of calcium oxalate + uric acid. This might be because of a protein (29 $\mathrm{kDa}$ protein) which plays a major role in epitaxial deposition of calcium oxalate over uric acid core, consequently favoring the lithogenic events. ${ }^{17}$ The main etiologic factors related to this type of renal calculi are urinary crystallization inhibitor (citrate, phytate) deficiency, urinary $\mathrm{pH}$ values below 5.5 and the presence of renal cavities with low urodynamic efficacy. ${ }^{27}$ Due to the double effect of citrate acting as a crystallization inhibitor and increasing the urinary $\mathrm{pH}$, citrate-rich foods or citrate drugs are the basis of the most effective dietary or pharmacological treatment for these calculi. $^{28}$ In such cases, the urinary $\mathrm{pH}$ must be controlled to avoid high values that could induce hydroxyapatite formation. In Southern Sindh, Pakistan calcium oxalate + uric acid stones are more common, ${ }^{30}$ however, some investigators have reported calcium oxalate monohydrate and calcium phosphate stones. $^{34,35}$ Diet may be the causative factor of calcium oxalate + uric acid stones. ${ }^{36-39}$

\section{CONCLUSION}

Calcium oxalate + uric acid stones are commonly found in patients of Hyderabad and adjoining areas.

\section{REFERENCES}

1. Jaeger P. Genetic versus environmental factors in renal stone disease. Curr Opin Nephrol Hypertens 1996; 5: 342 - 346.

2. Baggio B. Genetic and dietary factors in idiopathic calcium nephrolithiasis: what do we have, what do we need? J Nephrol. 1999; 12: 371 - 374.

3. Serio A, Fraioli A. Epidemiology of nephrolithiasis. Nephron Suppl. 1999; 81: $26-30$.

4. Rivers K, Shetty S, Menon M. When and how to evaluate a patient with nephrolithiasis? Urol Clin North Am. 2000; 27: 203 - 213.

5. Soucie JM, Coates RJ, Mc Clellan W, Austin H, Thun M. Relation between geographic variability in kidney stones, prevalence and risk factors for stones. Am J Epidemiol. 1996; 143: 487 - 495.

6. Siddiqui AA, Sultana T, Bucholz NP, Waqar MA, Talati J. Proteins in renal stones and urine of stone formers. Urol Res. 1998; 26: 383 - 388. 
7. Dussol B, Berland Y. Urinary kidney stone inhibitors: what is the news? Urol Int. 1998; 60: 69-73.

8. Curhan GC, Willett WC, Rimm EB, Stampfer MJ. Family history and risk of kidney stones. J Am Soc Nephrol. 1997; 8: 1568 - 1573.

9. Paluszkiewicz C, Jand S, Galka M. Analysis of renal stones by FTIR spectroscopy. Microchimica Acta. 1988; 94 (1-6): 45 - 48.

10. A Mayo Reference Services Publication. Kidney Stones and Stone Analysis. Communique 2001; $26(5): 1-6$.

11. Clegg $H$ and Ware $M$. Composition of kidney stones. Br Med J. 1965; 1: 1392 - 96.

12. Taylor DR, Crowther RS, Cozart JC, Sharrock P, Wu J, Soloway RD. Calcium carbonate in cholesterol gallstones: polymorphism, distribution, and hypothesis about pathogenesis. Hepatology. 1995; 22, 488 - 96.

13. Soloway RD, Wu J. Analysis of gallstones. In: Muraca $M$, editor. Methods in biliary research. Boca Raton (FL): CRC Press, Inc; 1995; Pp. 167-90.

14. Silverstein RM, Webster FX, and Kiemle DJ. In: Infrared spectroscopy, Bennon D, Yee J editors. Spectrometric identification of organic compounds. Seventh Edition, New York, John Wiley and Sons, Inc., 2005. Pp. $72-126$.

15. Maschio G, Tessitor N D, Angelo A, et al. Prevention of nephrolithiasis with low dose thiazide, amiloride and allopurinol. Am J Med. 1981; 71: 623-26.

16. Morton AR, Iliescu EA, and Wilson JWL. Investigation and treatment of recurrent kidney stone. $\mathrm{Ca}$ Med Assoc J. 2002; 166 (2): 213 - 16.

17. Michell AR. Urolithiasis - historical, comparative and pathophysiological aspects: A review. J Roy Soc Med. 1989; 82: 669 - 72.

18. Coe FL. Prevention of kidney stone. Am J Med. 1981; 71: $514-16$.

19. Pak CY, Adams-Huet B, Poindexter JR, Pearle MS, Peterson RD, Moe OW. Rapid communication: relative effect of urinary calcium and oxalate on saturation of calcium oxalate. Kidney Int. 2004; 66: $2032-2037$.

20. Coe FL, Andrew E, Woreoster E. Renal section,
University of Chicago, Chicago. Illinois, USA. The J Clin Inves. 2005; 115 (10): 2598 - 02.

21. Massey LK, Liebman M and Kynast-Gales SA. Ascorbate Increases Human Oxaluria and Kidney Stone Risk. J Nutr. 2005; 135: 1673-1677.

22. Ombra MN, Forabosco P, Casula S, et al.. Identification of a New Candidate Locus for Uric Acid Nephrolithiasis. Am J Hum Genet. 2001; 68: $1119-1129$.

23. Gianfrancesco F, EspositoT, Ombra MN, et al. Identification of a Novel Gene and a Common Variant Associated with Uric Acid Nephrolithiasis in a Sardinian Genetic Isolate. Am J Hum Genet. 2003; 72: 1479 - 1491.

24. Hamm LL, Simon EE. Roles and mechanisms of urinary buffer excretion. Am J Physiol. 1987; 253: $595-605$.

25. Hayashi M. Physiology and pathophysiology of acid base homeostasis in the kidney. Intern Med. 1998; $37: 221-225$.

26. Rieu P. Lithiases d'infection. Ann Urol (Paris) 2005; 39: 16 - 29.

27. Grases F, Costa-Bauza A and Prieto RM. Renal lithiasis and nutrition. Nutr J. 2006; 5: $23-29$.

28. Matalaga BR, Kim SC, Watkins SL, Kuo RL, Munch LC, Lingeman JE. Change composition of renal calculi in patients with neurogenic bladder. JAMA. 2006; 175 (5): 1662 - 3.

29. Wrongo and Davies HEF. The excretion in renal disease. Q J Med. 1959; 28: 259 - 311.

30. Khand FD, Khuhwar MY, Memon SU, Ansari AF. J Chem Soc Pak. 1991; 13(1): 19 - 24.

31. Ellis HA. History of bladder stones. Oxford, black well; 1969; 7: 56 - 59.

32. Baumann J. Can the formation of calcium stones be explined by crystallization process in urine? Urol Res. 1985; 13: 267 - 70.

33. Ryall R, Hibberd C, Marshall VA. Method for studying inhibitory activity in whole urine. Urol Res. 1987; 13: 285 - 9.

34. Fetter TL, Zimskind PD. Statistical analysis of patients with urinary calculi. JAMA. 1961; 186: 2123.

35. Grases F, Costa-Bauza A, Ramis M, Montesinos 
V, Conte A. Simple classification of renal calculi closely related to their micromorphology and etiology. Clin Chim Acta. 2002; 322:29-36.

36. Elliot JS, Rebiro ME. The urinary excretion of citric, hippuric, and Lactic Acid in normal adult and in patients with calcium oxalate urinary calculus diseases. Invest Urol. 1972; 10: 102 - 106.

37. Welshman SG, McGeorn MG. Urinary citrate ex- cretion in stones formers and in normal controls. Br J Urol. 1978; 48: 7 - 11.

38. Tiselius HG. In: Smith LH, Robertson WG, Finlayson $B$ et al. (eds). Urolithiases: clinical and basic research. Plenum pub, New York. 1980; Pp. 3944.

39. Parks JH and Coe FL. A Urinary calculi nephrolithiasis. Kidney Int. 1986; 30: 85 - 90.

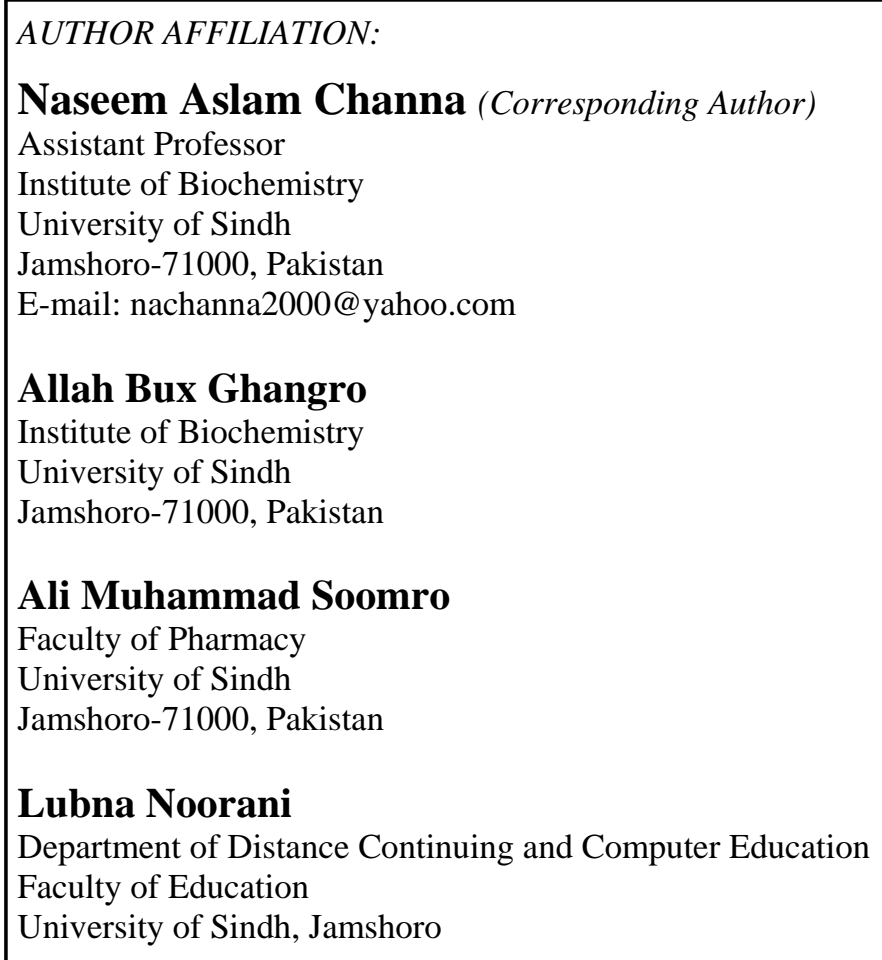

